\title{
WHITMAN ON ROBERT BURNS: AN EARLY ESSAY RECOVERED
}

\section{GARY SCHARNHORST}

"Walt Whitman, the American poet, has published in an American newspaper his estimate of the poet Burns," W. M. Rossetti reported in the London Academy in late February $1875 .{ }^{1}$ Remarkably, Whitman's early critical essay on Burns has hitherto been lost to scholarship. It was first printed in the January 25, 1875, issue of an ephemeral paper entitled Our Land and Time-a periodical so obscure it is not catalogued by the Union List of Serials, the Union List of Newspapers, the National Union Catalogue of pre-1956 imprints, or the OCLC on-line database. Fortunately, it was copied the same day in the New York Daily Graphic, a paper to which the poet sometimes contributed, from which it is here reprinted. Whitman later revised the essay for publication in the New York Critic (December 16, 1882); in the North American Review under the title "Robert Burns as Poet and Person" (November 1886); in November Boughs, Democratic Vistas and Other Papers, and Complete Poems E Prose (all 1888); and finally in Complete Prose Works (1891-92). In lieu of a detailed collation of all versions, I have underlined here the passages omitted from Whitman's subsequent essays on Burns; that is, I highlight the material, totaling several hundred words, new to Whitman scholarship. ${ }^{2}$

\section{ROBERT BURNS.}

\section{A MODERN POET ON THE SCOTCH BARD.}

(From our Land and Time, fanuary 25, 1875.)

To-day, and especially to-night at the suppers and drinks and speeches, how much will be said, to be afterwards gradually filtered through East and West, North and South, about Robert Burns particularly and about poets and poetry in general; to-day, the 116th anniversary of that birth-time when Rob, like the vast majority of us, entered upon the stage amid cheapest surroundings, commonest accompaniments, and nobody to make any extra note of it!

First premising to thee, reader dear, that the undersigned has been courteously summoned by letter and ticket to more than one of to-night's supper anniversaries, the way may then be clearer and the reason why for thoughts like the following, not of extravagant eulogium, with voice pitched high and fervent to the pleasant smell of hot Scotch, but alone by the fireside in the invalid room, weighing the canny Caledonian bard in friendly scale, yet seeking to strike the eternal averages. 
The study of poetry and the poets-needed for these States and to our 1875 and '76 the same as ever, and for modern democracy just as much as past-time feudalism and ecclesiasticism - remains a vivid and profound study, only demanding some new interpellations. In certain respects it is profounder than science (whose conclusions, in my opinion, poetry should henceforth proceed to involve). ${ }^{3}$ It leads far beyond the rhymes and thin gauze and sentimentalism of the magazines. And I may say here what for some time I have not hid from my friends-an opinion that the distinctive Democracy and new life which America stands for, are yet to receive their best proof and crowning charm from native outgrowths of verse and imaginative literature adjusted to them, reaching far deeper and higher even than our politics, election-days, and our free and universal ballot.

By America and her Democracy such poets as the one under notice must be kept in loving remembrance; but it is best that discriminations be made. The admirers of Burns at these anniversary speeches and occasional lectures, I notice, will not accept for their favorite anything less than the highest rank, alongside of Homer, Shakespeare, \&c. Such, in candor, are not the true friends of the Ayrshire bard, who really needs a different place quite by himself. The classical Iliad and the Odyssey express war, courage, craft, full-grown heroism, \&c., for the whole human race, in situations of danger, the sense of command and leadership, emulation and god-like even though animal appetites. The English Shakespearian compositions on vertebres and framework of the primary passions portray the spirit and letter of the feudal world, the Norman lord, ambitious and arrogant, taller and nobler than common men, with much underplay and gusts of heat and cold, volcanoes and stormy seas.

Burns (and some will say to his credit) attempts none of these themes. $\mathrm{He}$ expresses the sulks, humor, riotous blood, amorous torments, fondness for the tavern and for cheap objective nature, with disgust at the grim and narrow ecclesiasticism of his time and land, of a young farmer on a bleak and hired farm in Scotland, through the years and under the circumstances of the British politics of that time, and of his short personal career as author, from 1785 to 1796 . He is of independent spirit, jovial (although a born hypochondriac), very manly ${ }^{4}$ and affectionate, and just emerged or emerging from the shackles of the kirk, from poverty, ignorance, and from his own low appetites; out of which latter, however, he never extricated himself. It is to be said that amid not a little smoke and gas in his poems there is always a spark of fire, and now and then the real afflatus. Some of his songs of lads and lasses and of natural objects are incomparable. It is also to be distinctly avowed that one cannot know the person Robert Burns, what we get of him, without a deep brotherly yearning towards him.

Burns has been applauded for our purposes as democratic, and with some warrant; while Shakespeare, and with the greatest warrant, has been called monarchical or aristocratic (which he certainly is). But the splendid personalizations of Shakespeare, formulated on the largest, freest, most heroic, most artistic mould, are to me far dearer as lessons, and more precious even as models for Democracy, than the humdrum samples Burns presents. (To be plain, the new dispensation of Republicanism is not over-well served by its bards, so called, anywhere; the singers of feudalism and ecclesiasticism, after all, have served it better.)

Though there is always this point, and of the very highest, to be made in favor of Burns. The recognition of generous and powerful typical character, either in its standards in the world of things or moral and aesthetic standards, pervades him throughout. To completely formulate that ideal perfection for the acceptance of the United States is yet unknown in literature. To realize it, seek it, act upon it, is a help not to be dispised. A poet or artist in whose productions this fervid recognition is discovered, and by whom its realization is personally striven for (perhaps amid many escapades and errors), will often be dearer to the race than others even of 
more correct life and superior technical art. (Byron, George Sand, Schiller, and Burns illustrate this.)

Not only the homely virtues but the heartiest comradeship and affiliation are in Burns. Good-will to all men and women - and even to ponies, dogs, and micesheds a glow on every page. This sweetest and most democratic of emotions never had a more genuine, more touching exponent - perhaps never one so good. In it even the great planets mentioned pale their light to his. To the crucial questions of all, Is he a poet indeed? and, Are the results of reading and familiarity with his works finally beautifuing and elevating and health-inculcating? - the answer, I am clear, must be a prompt and unmitigated Yes to both.

He has, however, little or no spirituality. This is his mortal flaw and defect, tried by highest standards. The ideal he never reached (and yet I think he leads the way to it). He gives melodies, and now and then the simplest and sweetest ones; but harmonies, complications, oratorios in words, never. (I do not speak this in any deprecatory sense. Blessed be the memory of the manly and warm-hearted Scotchman for what he has left us, just as it is!) He likewise did not know himself, in more ways than one. Though so really equal and independent, he prided himself in his songs on being a cavalier and a Jacobite. ${ }^{5}$ We shall have to call him a poet of the third, perhaps fourth class.

It will be seen that we take our observation of this poet, not so much from the zealous points of view of his clannish and foreign race (for to America he and all of them, are they not foreigners and clannish enough?) but by considering him as an individual one amid the crowded clusters, galaxies of the old world, and by fairly inquiring and suggesting what out of those myriads he too may be to us, to America. ${ }^{6}$ For it is worth while-is it not? - that for a change, anyhow, St. Andrew, St. George, St. Patrick, St. Dennis, and every other imported saint should see how he appears when viewed through the optics (spectacles, if you please) of St. Jonathan.

Thus, while Burns, from these points of view, is not only not great (for New World study, and for mere reminiscences, like all the rest of them), in the sense that Isaiah and Aeschylus and the Book of Job are unquestionably great-is not to be mentioned with Shakespeare-hardly even with our current Tennyson and Emerson-he has a nestling niche of his own, all fragrant, fond, and quaint and homely - a lodge built near but outside the mighty temple of the gods of song and art-those universal strivers, through their works of harmony and melody and power, to ever show or intimate, for our New World just as much as any, or more than any, man's crowning, last, victorious fusion in himself of Real and Ideal.

WALT WHITMAN.

With the recovery of this version of Whitman's essay on Burns, we may now trace more fully its development through three major drafts (those published in 1875, 1882, and 1886). It seems that Whitman later qualified or muted his harshest judgements of Burns (e.g., deleting his assertion that he was "a poet of the third, perhaps fourth class") and gradually modulated the intensely patriotic tone of the piece (e.g., omitting the claim that he read Burns "and every other imported saint" through the lens of "St. Jonathan"). Still, and for obvious reasons, the American bard was fascinated by the example set by "the canny Caledonian bard" and repeatedly tried to gauge his achievement. As Sarah Blacher Cohen notes, "Burns the ploughman offers Whitman proof that laboring classes may produce 
poets as easily as the nobility." Or as Whitman allowed privately to Horace Traubel, Burns was "as dear to me as my old clothes!"

\section{University of New Mexico}

\section{NOTES}

1 "Notes and News," London Academy, February 27, 1875, 214; Whitman, The Correspondence, ed. Edwin Haviland Miller (New York: New York University Press, 1961), 327n.

2 “Robert Burns," New York Daily Graphic. January 25, 1875, 610.

3 Whitman struck a similar note the next year in the preface to the Centennial Edition of his poetry: "without being a scientist, I have thoroughly adopted the conclusions of the great savans and experimentalists of our time, and of the last hundred years, and they have interiorly tinged the chyle of all my verse" (Prose Works 1892, ed. Floyd Stovall [New York: New York University Press, 1964], 2:472).

4 Whitman later revised this line to read as follows: "The basis of his character with all its fun and manliness was hypochondria" (Prose Works 1892, 567).

5 Whitman later revised this line to read as follows: "Though so really free and independent, he prided himself in his songs on being a reactionist and a Jacobite" (Prose Works 1892, 565).

6 Whitman later replaced "America" with "the Western Republic" (Prose Works 1892, 560).

7. Sarah Blacher Cohen, "Walt Whitman's Literary Criticism," Walt Whitman Revir 18 (June 1972), 49.

8 Horace Traubel, With Walt Whitman in Camden (New York: Appletor $2: 436$. 